ERIK DE GIER*

Radboud University, Nijmegen

https://doi.org/10.26485/PS/2018/67.3/8

\title{
MODERNIST INDUSTRIAL NOVELS AND INDUSTRIAL SOCIOLOGY. A COMPARISON BETWEEN WEIMAR GERMANY AND POST-WWII ITALY
}

\begin{abstract}
Since the English Industrial Revolution in the $18^{\text {th }}$ century the industrial novel has played a significant role in industrialized countries by making workers, politicians, policy makers and the general public aware of actual working conditions in industry and services. Also, these novels contributed positively to workers emancipation. Well-known examples are the industrial novels of the English Victorian writers Dickens and Gaskell. Also in other countries the industrial novel developed into a well-known literary genre linked with the process of industrialization. In France Zola's "naturalist" industrial novels had a significant influence on labour policies at the time of the Third Republic. After the turn of the $19^{\text {th }}$ century the industrial novel also became manifest in other industrialized countries: before World War I in the USA, by the Inter-bellum in Germany and the USSR, and after World War II in Italy. Often these novels were based on desk research or empirical research on-site. Therefore, these novels are also expressions of pseudo- or ex-ante sociology, regretfully underestimated in vested industrial sociology. By comparing and juxtaposing industrial novels written in two important European industrial countries in two different time periods, Weimar Germany in the 1920s, and post-war Italy in the 1950s and early 1960s, I will illustrate this.

Keywords: industrial novels, industrial sociology, sociology of work, history of work
\end{abstract}

* Prof. dr, Professor emeritus, Institute of Management Research; e-mail: e.degier@fm.ru.nl 


\section{INTRODUCTION}

In 2016, I published a book on the introduction of, sometimes encompassing, enlightened but principally paternalistic welfare work programs in capitalist enterprises during the heydays of capitalism between 1880 and 1930 in Great Britain, the USA, France and Germany [De Gier 2016]. Noteworthy examples were steel enterprise Krupp in the German Ruhr-region, as well as steel enterprise Schneider in French Burgundy, Cadbury's chocolate factory at Bourneville (England), and a number of textile and steel mills in the USA. These companies introduced encompassing welfare work initiatives and in fact created preliminary mini-welfare states in their enterprises. By paying attention to this almost forgotten chapter of labour and industrial history I hoped to demonstrate two things. First of all, I wanted to point to the, in my opinion, remaining significance of an also historical approach in the context of industrial sociology. Industrial sociology gradually has become an applied discipline momentarily partly overhauled by a-historical academic approaches, such as strategic human resources management. In my opinion this has been caused by the fact that the main body of knowledge of industrial sociology, as well as its practical applicability nowadays has become obsolete to some extent in the context of the fundamental transition of the industrial society based on solidarity and class-consciousness towards a liquid non-industrial society in which the applicability of this discipline no longer is naturally [Bauman 2000].

Secondly, by applying a historical angle and by coupling this subsequently with present day industrial and labour relations I also intended to show that we could still learn significantly from past experience.

In this article I tend to follow a similar, albeit "flipside" historical-sociological approach by focusing on a selective sample of industrial novels written in different time periods of capitalism in two industrializing or industrialized countries. In my opinion, as in case of enlightened entrepreneurial welfare work initiatives in the past, also industrial novels are an almost neglected matter in the context of industrial sociology. However, such novels may also be considered as useful forms of ex-ante sociology, particularly in those cases where these novels are not fully fictitious but partially based also on empirical sources.

\section{THEORETICAL AND METHODOLOGICAL BACKGROUND}

Considering industrial novels in a time perspective, a meaningful distinction can be made between "traditional", "modern" and "post-modern" industrial novels. Roughly seen "traditional" industrial novels date back to the time period before 
World War I, whereas "post-modern" industrial novels emerged in the $21^{\text {st }}$ century, as for example is the case with Dave Eggers' recent The Circle [Eggers 2014]. In this article I will focus on "modern" industrial novels written in the period after World War I and the 1950/1960s.

As has been stated, industrial novels deal with work and work-related problems of workingmen in an industrializing or industrialized context and as such are considered as a sub-genre of the so-called social novels. The first "traditional" industrial novels dealing with the quality of working and living conditions of working men were written in England from the onset of the English industrial revolution with the intention of questioning workingmen's exploitation by capitalist entrepreneurs ${ }^{1}$. The flowering period of the English industrial novel was the $19^{\text {th }}$ century Victorian period with well-known authors as Charles Dickens, Elisabeth Gaskell, George Elliot, Benjamin Disraeli, and William Morris [Williams 1963, 99-119]. After England the industrial novel rapidly spread to other countries on the European continent and the USA. By the end of the nineteenth century Emile Zola dominated this genre in France. Germinal, a novel on working and living conditions of a French miners family in Northern France is his best-known 'naturalist' industrial novel written during the Third Republic. After the turn of the $19^{\text {th }}$ century American author Upton Sinclair started to dominate the genre for a while in the USA. His books on the working conditions in the Chicagoan meat industry, on Ford and on the American coal mining industry have become very well known.

The modernist industrial novels with which I will deal hereafter concern industrial novels written in Weimar Germany in the 1920s and early 1930s and in post-war Italy in the 1950s and early 1960s. The nature of these industrial novels differs in two more fundamental aspects with "traditional" industrial novels written before in other countries.

First of all, by contrast to former "traditional" industrial novels the political aspect appears to be more pronounced in industrial novels written in Weimar Germany and Post-war Italy. Although also the Victorian industrial novels and Zola's and Sinclair's industrial novels undoubtedly influenced social politics in their respective countries it is no exaggeration to contend that the objectives of Weimar and post-war Italian industrial novels as such had a wider ambition. In both cases in the background the influence of class struggle in rapid changing economic circumstances as well as the influence of national socialism (in case

1 Before the take-off of the industrial revolution in the 18th century in England industrial novels were preceded by utopias, which sketched imaginary idealistic futures humanity as for example the famous Utopia of Thomas More dating back to 1516 [More 1965]. 
of Weimar) and communist or Marxist political parties (in case of both Weimar and post-war Italy) is sensible, as well as a general wish for fundamental social change. The same could be said with respect to for example industrial novels in Stalin's USSR [Colombo 2008], and to a lesser extent to Dos Passos's famous trilogy USA [Dos Passos 1938/1966] and George Orwell's The Road to Wigan Pier on bad working and living conditions of coal miners in the north of England in the 1930s [Orwell 1937/1979].

Secondly, related to the first aspect, in order to be able to understand and interpret Weimar and Italian industrial novels correctly it is necessary to consider its specific modernist nature more precisely. This requires the introduction of two interrelated terms: New Objectivity and Constructivism. Both terms are primarily linked with avant-garde-art which developed in various countries in the aftermath of World War I. Well-known expressions of avant-garde art were, for example, German and Russian Expressionism (Kirchner, Nolde, Die Brücke, Dada, Kandinsky, Malewitsch), Cubism and Italian Futurism (Marinetti) [Bowlt, ed. 1988: xix-xl]. It is important that the avant-garde did not limit itself to painting but also involved other forms of art, such as architecture (Bauhaus), cinema, and literature. A central characteristic of the avant-garde movement was the idea that art was not a goal in itself, but also had to contribute to societal progress, social change and even to a new and more just world [Todorov 2009: 193-230]. Jointly, different avant-garde art forms could construct a new objective reality. With respect to industrial novels this implied that instead of mere fiction the social reportage or documentarism at least partly based on empirical data and facts became the dominant form of the industrial novel in the Weimar Republic as well as in Stalin's USSR, the USA in the 1930s, Britain in the 1940s, and Italy in the 1950s².

Hereafter I will illustrate the fundamental transformation in the nature and form of the "traditional" industrial novel into the "modern" industrial novel, which took place during the Inter-bellum respectively on the basis of two cases: Weimar Germany and Italy in the 1950s and early 1960s. I will deal more specifically with a few high-profile authors of industrial novels in both countries at that time and compare and interpret their most important industrial novels. However, it is not my intention to carry out an extensive content analysis of these novels. My sole objective is to compare and to contextualize these novels in a sociological-interpretative way with the intention of highlighting their complementary significance for industrial sociology.

2 There had been some exemplary forerunners of the social reportage in eighteenth century England and fin-de siècle France [Engels 1993; Zola 1885/1991]. 


\section{WEIMAR INDUSTRIAL NOVELS: KRACAUER, KISCH AND REGER}

The New Objectivity in the German industrial novel was primarily expressed in the work of Siegfried Kracauer, architect, philosopher and a (leftist) journalist of the Franfkurter Zeitung (a leading Frankfurt paper at that time). Kracauer was linked to the so-called Frankfurt School of sociology through his friends Theodor Adorno and Walter Benjamin. More in particular his literary ambitious Die Angestellten [1930] - published in English as The Salaried Masses - dealt in an ethnographic and also dialectic way with white-collar workers in Berlin offices and department stores by the end of the 1920s. It is a classical example of the New Objectivity-industrial novel. Two more representative examples, which also will be discussed here briefly, are: Der rasende Reporter by Egon Erwin Kisch [Kisch 1924/2006] and Union der Festen Hand by Erik Reger [Reger 1931/1992] ${ }^{3}$.

Siegfried Kracauer's Die Angestellten was first published in 1930 [Kracauer 2013]. This relatively small book contains some twelve brief, but very concise essays describing the transformation of working life and working culture in Berlin in the 1920s impressively. Then, Germany's capital had become one of its biggest and most industrialized cities. The at the time on-going transformation of working life Siegfried Kracauer wanted to depict, was the revolutionary increase of white collar workers, for a large part women, in big industrial and financial enterprises. His book, covering an until that moment more or less terra incognita, dealt particularly with the culture and lifestyle of the new white-collar proletariat. The chosen form was the reportage, or in this case more appropriately, a "montage, that is a mosaic of photographs or samples of reality" [Später 2016: 230]. It was mingled with various kinds of relevant statistical and documentary data. For example, in the 1920s hundred-thousands of white collar workers daily populated Berlin's streets, while in Germany as a whole the number of white-collar workers reached the figure of 3.5 million, inclusive 1.2 million women. Whereas the increase of blue-collar workers only doubled, the increase of white-collar workers at the time was five times higher than before. Half of white-collar workers were occupied in industry, local government and social security organizations, and the other half in commerce, traffic and banking. Most numerous were office

\footnotetext{
Although not strictly a Weimar industrial novel, in this context worth mentioning is also Das Leben der Autos by the Russian writer Ilja Ehrenburg published in 1929 in both the Soviet Union and Germany. Its style is Neo Objectivity and its form is reportage, chiefly about the assembly line production of Citroën cars in France and Ford automobiles in the USA in the 1920s, a time of rationalisation, increasing speed, increasing importance of transportation and globalisation [Ehrenburg 1983].
} 
workers, workers in commerce, technicians and foremen. About thirty per cent of the white-collar workers were organized in one of the then three white-collar labour unions [Kracauer 2013: 10-16].

The main background characteristic of the transformation of working life and the organization of work were the intensifying processes of rationalization (introduction of scientific management and Fordism) and mechanization (introduction of assembly lines) in the German economy, which was occurring for the first time at full scale in German industry and the new services industries. The rapid increase of white-collar workers in this context, both in industry and services, also resulted in the creation of a new manifest until that time absent white-collar culture. That is a culture particularly constructed and perceived by white-collar workers themselves, for example by celebrating extensively weekend entertainment activities and actively exercising sports as new ways of a "fashionable life". This culture turned out to be, so Kracauer, "spiritually empty" and did not prevent worker alienation and feelings of anomia among the Berlin middle class (geistige Obdachlosigkeit) [Kracauer 2013: 15; Kaes et al. 1994: 181-194].

Kracauer was convinced that, contrary to let us say one hundred separate factory descriptions, the documentary reportage was an eminent means to construct working life reality. The way he created his reportage was in a certain way similar to formal sociological research ${ }^{4}$. For example, in order to be able to diagnose correctly the reality of working life changes he conducted first of all a large number of interviews with different types of white-collar workers and their representatives at the company level, and also with entrepreneurs, members of the personnel department of companies, and representatives of white-collar labour unions. He also carried out participant observations on-site and additionally, used relevant social research citations. Remarkably, Kracauer himself didn't have the explicit intention of formulating practical reform proposals on the basis of his approach. Rather, he considered his cases as exemplary for reality. The results of his efforts were published first as a feuilleton in the Frankfurter Zeitung by the end of the 1920s and later also in book form. Interesting is that Kracauer approached his subject not only from different perspectives (workers,

4 Contrary to other New Objectivity-industrial novels, according to Walter Benjamin, Kracauer himself did not like to see his approach as a mere New Objectivity-reportage. He preferred to offer something fundamentally different, namely a further reaching and more in-depth dialectical "unmasking" approach. See: Benjamin, Walter 1930, Politisierung der Intelligenz. In: Siegfried Kracauer 2013: 116-123. Also published as Ein Aussenseiter macht sich bemerkbar. [Benjamin, Gesammelte Schrifte, Werkausgabe, Band 3 1980: 219-225]. 
bosses, trade unionists), but also by depicting the New Berlin white-collar culture through various aspects, such as the absenteeism of a worker community, the high incidence of worker alienation in case of rationalized and mechanized office work, lack of work satisfaction, planning of work processes, introduction of welfare work, introduction of letterbox-suggestions and career development, the significance of worker age, tariffs, internal company papers, educational level of white-collars, and their consumptive needs. In his approach Kracauer did not shun the use of various illustrative metaphors as well as nicknames, such as cyclists (Radfahrer) flattering of chiefs and bossing lower levels, mucous gowns (Schleimtrompeten), princesses (Prinzessinen), and blood oranges or hypocrites with "yellow skins and red insides" (Blutorangen).

All in all, his book resulted in a very comprehensive and succinct description of the white-collar culture at the time in Berlin and also the Weimar Republic, which one could summarize as a new, uniform middle-class mass culture, with comparable uniform labour relations and collective agreements. Compared to the more traditional blue-collar industrial proletariat, the new white-collar proletariat in Berlin of the 1920s was distinct because it was "spiritual homeless" caused by alienating white-collar work and a flight ahead towards non-politicized weekend amusement and fascination for sports. Kracauer's approach fitted narrowly in the theoretical approach of the Frankfurt School of sociology, which focused from a dialectical and Freudian psychoanalytical perspective on the correlation of the rise of the new middle class and national-socialism in the Weimar Republic and the failure of the German Revolution in 1919 [Jeffries 2016: 7]. However, Kracauer transformed Marxism into culture criticism by contending that the new white-collar proletariat in the Weimar Republic did not feel any affinity to the Marxist class model [König 1987: 234].

A second important example of the New Objectivity-industrial novels in the form of reportage is Der rasende Reporter (The Raging Reporter) by writer and journalist Egon Erwin Kisch [1885-1948], first published in 1924 [Kisch 2006].

Kisch considered the reportage as a form of literary art in which he combined skillfully observation and narrative. In his own words, "nothing is more amazing than the simple truth, nothing is more exotic than our environment, and nothing is more imaginative than objectivity"s.

In Der rasende Reporter, Kisch presented a large quantity of documentary reports on a large variety of subjects like the well-known Parisian flee market at

5 Nichts ist verblüffender als die einfache Wahrheit, nichts ist exotischer als unsere Umwelt, nichts ist phantasievoller als die Sachlichkeit [Später 2016: 229]. 
Clignancourt, homeless people in London, a shipping exchange, a six-day cycling track match, and a Yiddish literary café. Three of these brief essays deal with industry and work, and more in particular with the heavy coal and steel industry in the Ruhr-region. Subsequently these three reportages offer an illustrative impression of the Krupp steel company in Essen and its then extensive welfare work program and welfare work institutions, the heavy working conditions and labour relations in a blast furnace and cokes factory at Bochum, and finally of the group of important German mining and steel entrepreneurs during the annual gathering of shareholders in a luxury hotel again at Essen, the then coal and steel capital of the industrial Ruhr-region.

In the Krupp-reportage Kish talks among other things about Reiche ... Kr. or Krupp-empire in Essen, which owned almost everything in the new industrial suburb Westend and by this controlled almost the whole life of its inhabitants. In Westend we do not only find its cast steel factory, but also a Kr.-churchyard, a Kr.-hospital, a Kr.-consumers union, a Kr.-memorial, etc. Westend, in the eyes of Kisch, actually was the new Essen, which overhauled and dominated from now on the old town. This reportage breathes a strong tension between the huge weaponry profits of the Krupps during World War I and 'Essen's tortuous streets and alleyways, which are narrow-breasted, hunchbacked and frightening [engbrüstig und buckli und schlotterend] like the bodies of the workers inhabiting this troglodyte kingdom' [Williams 1990: 103].

In the enormous steel mill at Bochum the workers in the blast furnace were working continually in three shifts per day during their whole life in bad working conditions. Remuneration was modest, by and large 120 marks per month in case of the best performing workers.

Finally, the heavy industry shareholders meeting at Essen was dominated by the then prominent and intertwined entrepreneurial "types" who managed the German economy like Thyssen, Kirdorf and Stinnes. Although officially the meeting was a democratic public gathering, press was not allowed. Contradiction was not done in this context of the "big cumulative undertaking" of the German heavy industry, then responsible for the delivery of electricity and light in a large part of the country.

The third and last example of the New Objectivity industrial novel in Weimar Germany is Erik Reger's Union der festen Hand [1931/1992]. This book is widely considered as the best industrial novel in Germany of this time period. Again, this book is more reportage than novel like the other books mentioned here. For a time Reger (ps. for Hermann Dannenberger, 1893-1954) worked for the Krupp Company at Essen as a press officer. So he knew this company very well from the 
inside. His extensive book, containing more than 600 pages, is a concise objective non-partisan reconstruction of the labour struggle inside the Krupp Company in five subsequent episodes during the 1920s, encompassing the socialist uprising following the German defeat of World War I, the Kapp-Putsch, the French Occupation of the Ruhr region, economic stability in the mid twenties, inflation and rising mass-unemployment by the end of the 1920s, and ultimately the swift rise of Hitler and Nazism at the beginning of the 1930s. The book also deals with the internal rivalries amongst the big Ruhr-region industrialists. Moreover, Reger offers a very good impression of Krupp's welfare work policy and labour relations at the time. The Krupp Company appears encrypted as the Risch-Zander steel company, and its workforce as Rischianer instead of the factual Kruppianer, constituting "one big family" of workers and the entrepreneur and his family, living in a large number of sometimes romantic worker colonies with shops, and all kinds of other facilities, and in the monumental entrepreneurial Villa (Villa Hügel) respectively in larger company town Essen. Though in its extensive form not fully comparable to Kracauer's book, Reger's book in its core may also be considered as a "vivisection" of its time, dealing with worker alienation [Hermand 1965: 114; Muller 2014].

\section{THE ITALIAN INDUSTRIAL NOVEL IN THE 1950S AND 1960S: OTTIERI, VOLPONI AND OTHERS}

Italy underwent a remarkable strong economic boom (the so-called boom economico) in the 1950s and the beginning of the 1960s marked by a forceful industrialization [Ginsborg 1989: 283-343]. Italians themselves speak of a "second industrial revolution" after a former one by the end of the nineteenth century until the outbreak of the Great Depression of the 1930s. In a quick pace the country transformed itself from a still chiefly agricultural nation into one of the most important industrial economies of the world of that time. This transformation required the recruiting of many new industrial workers from the ranks of agricultural workers in a rather brief timespan. This incited large migrant streams from the south of Italy to the north, as well as a rapid urbanization of the North. The majority of important industrial enterprises like Fiat, Pirelli and Olivetti were concentrated into the so-called economic industrial triangle between Milan, Turin and Genoa. Another relevant factor in this context was the will of a great number of intellectuals and social reformers in the country to overcome the political and moral deficit of the previous fascist regime of Mussolini [Bonura 1972: 25]. This, among other things, motivated a limited number of enlightened 
and reformist entrepreneurs to experiment with industrial democracy and sometimes wide-ranging social policies inside their companies. One of the most outspoken and remarkable reformist entrepreneurs in this respect was Adriano Olivetti, the owner of typewriter-producing company Olivetti, first in the factory at Ivrea near Milan, and then also in the new factory in Pozzuoli near Naples. Adriano Olivetti strongly believed in the application of social science at the entrepreneurial level as well as in a narrow collaboration between entrepreneurs and intellectuals [scientists, writers, poets] in this context [Ferrarotti 2015; Ochetto 2013]. In this Olivetti certainly was not unique. In and around the same time, in the 1950s, a number of enterprises started with the introduction of externally oriented company journals, in which renowned scientist, designers, architects, philosophers, writers, poets and arts critics were involved actively. One of the most notorious examples in this respect was the journal Civiltà delle Macchine (1953-1979) founded by well-known writer and also engineer Leonardo Sinisgalli and engineer Giuseppe Eugenio Luraghi on behalf of Finmeccanica. This enterprise, a post-war conglomerate of a number of big Italian manufacturing industries like car producer Alfa Romeo, Ansaldo, and Cantieri Navali dell'Adriatico, was founded in 1948 with the intention of contributing actively to the reconstruction of the manufacturing industry of the country ${ }^{6}$. Civiltà delle Macchine and other comparable company journals dealt with subjects like technical innovations, product development, the economic boom of the $1950 \mathrm{~s}$, entrepreneurial welfare work policies, and the marketing of products. The particular intention of Civiltà delle Macchine was confronting in debate form two until that time opposite cultures in industry: the technical and the humanistic. This resulted in a number of remarkable narrative and descriptive articles on the cultural role of post-war Italian "enlightened" capitalism, partly based on so far lacking "unique" factory visits [visita in fabbrica] and direct observations of working life and working conditions of writers and other intellectuals. Until that moment this had never happened in Italy [Di Nardo 2009; Bigatti, Luppo 2013; Alberini 2014]. Some interesting self-explanatory examples of factory visits are the following articles: Un poeta e un pittore in visita ai cantieri dell'Ansaldo (A poet's and painter's visit to the Ansaldo works) by Giorgio Caproni (1953), La centrale di Cornigliano (The powerplant of Cornigliano) by Carlo Emilio Gadda (1953), and Ritorno alla Sant'Eustacchio (Return to the machine factory Sant'Eustacchio) by Emilo Tadini (1956) [Bigatti, Lupo 2013: 115-140].

6 Other examples are Comunità (Notizie Olivetti), Pirelli (Pirelli), Il Gatto Selvatico, and Rivista Italsider. 
Apart from the journals mentioned here, another significant event regarding the incidence and development of the post-war Italian industrial novel was a remarkable initiative taken by two authoritative and well-known writers Elio Vittorini and Italo Calvino. In September 1961 they published a special number of the new important neo-realistic literary journal Il Menabò di letteratura (founded in 1959), which was completely devoted to the actual Italian industrial novel. The journal's objective was, like Civiltà delle Macchine, to anticipate directly on the fundamental economic and social transformation of Italy during the period of the very forceful economic boom of the country by paying attention to the spectacular growth at the time of the chemical, automobile and electro-domestic industries, the need of social reforms at the entrepreneurial level, social inequality, the rapid urbanization of the North caused by emigration from south to north, the construction of motorways, and real estate speculation.

In the background the Italian communist party (PCI) also played a crucial role, of which both Calvino and Volponi were active members ${ }^{7}$. Its cultural department tried to influence directly the by Vittorini and Calvino initiated writers' debate on the industrial novel which gave for the first time in the Italian industrial novel a direct voice to the worker. In line with the ideas of famous Italian communist Antonio Gramsci, imprisoned in the 1930s by Mussolini, Calvino took the stance that an intellectual should come close to the people in order to be able to produce a letteratura nazionale populare (popular national literature), whereas the PCI took the more rigid stance of socialist realism and zdanovism ${ }^{8}$ [Fioretti 2013: 13].

By publishing a special number on the industrial novel Vittorini and Calvino wanted to give the industrial novel, which in fact already existed in Italy in a more naturalist form since the 1930's, a new neo-realistic boost ${ }^{9}$. Both influential writers, similar to Civiltà delle Macchine and the other company journals mentioned, also considered the factory as a still closed institution, which urgently had to open its windows to the outside world for a critical sociological and anthropological examination of the new Italian industrial reality and the changing world

\footnotetext{
7 After the Hungarian uprising in 1956 Calvino, as many other members of the PCI, left the party.

8 Zdanovism concerned a narrow theoretical an practical control of activities of writers and intellectuals by the state or communist party to adapt them to the ideology or politics of the state/ party. [lo Zingarelli dizionario: Zanichelli 1917].

9 Fioretti considers 1934 as the year in which the modern realistic Italian industrial novel found a clear starting point, in particular with Carlo Bernari's novel Tre operai (Three blue collar workers). For the first time in the Italian industrial novel the worker himself became a subject and also got a direct voice. [Fioretti 2013: 11].
} 
of work [Vittorini 1961: 19]. As a consequence the Italian literary world linked to Menabò contributed actively to the renewal of the industrial novel in Italy. In this context one big enterprise (Olivetti) and two important writers in particular deserve further attention here, Paolo Volponi and Ottiero Ottieri.

As has been stated Olivetti stood at the forefront in post-war Italy with regard to welfare work reforms. It was famous for its enlightened welfare work programs, which encompassed a number of social services, health care provisions, community centers and a famous company library. Adriano Olivetti also founded the Olivetti company journal Comunità, a publishing company (Edizioni Comunità), and a Third-way political movement, which intended to renew Italian politics (Il Movimento di Comunità). Il Movimento, more precisely, aimed at promoting work and industry not only as means for gaining profit and distributing wealth equally, but also as a humanistic means for personal self-development, workers well-being, spiritual enrichment and social innovation.

Adriano Olivetti narrowly collaborated with a number of writers, most important amongst them Paolo Volponi (also nicknamed "il romanziere-sociologo") and Ottiero Ottieri. Both authors also worked for a certain time for Olivetti in the personnel departments of the factories at Ivrea and Pozzuoli respectively. They both published authoritative and influential industrial novels based on their company experiences.

Paolo Volponi (1924-1994), deeply influenced by the so-called "Olivettian model" as well as personally by the in the 1960 passed away Adriano Olivetti [Fioretti 2017: 24] published in the course of time various industrial novels and prose. Most important in the time period under consideration is Memoriale [Volponi 1962/1974]. At a later moment Volponi also published two other industrial novels: Corporale [Volponi 1974] on worker alienation, and Le Mosche del capitale [Volponi 1989] - generally considered as his most important novel - on the triumph of neo-capitalism over enlightened capitalism from the 1960s onwards and its effects on working life (the definite rise of the consumer society and the implicit historical defeat of the working class). Volponi's work as a whole may be considered as utopian as it is very narrowly related to the Olivettian corporal utopia, but it is at the same time contradictory by mixing pessimistic and optimistic visions about the practical possibilities of realizing ultimately an industrial utopia [Fioretti 2017].

Volponi got acquainted with Adriano Olivetti in 1950 and subsequently went working for the Olivetti Company in 1956 until 1971, at the main plant at Ivrea near Milan, where he ultimately became director of human resources. At that time the Olivetti Company employed some 50.000 workers worldwide. On personal 
request of Umberto Agnelli, Volponi moved to Fiat in Torino as a counselor in 1972. However, he got dismissed two years later after publicly confessing being a member of the Italian communist party. In 1983 he was elected as a senator for the PCI.

Memoriale is a novel devoted to worker alienation and its psychological effects as well as to labour conflicts by mixing Freudian and Marxian elements. Its main protagonist and voice in the book is Albino Saluggia, a to Piedmont returned sickly German prisoner of war with a traditional farming background. As a labourer he finds work in a big factory in the North of Italy (presumably the Olivetti plant at Ivrea). Saluggia perceives the well-organized factory as a system (based on scientific management and Fordism) and with a professional medical service as operating against his personal interests. Because of this he becomes paranoid and sees a company-complot emerging against him, which prevents him from having a normal working life. He also feels estranged by his work, which consists of monotonous and repetitive tasks. In this 'neurotic' factory context, Saluggia gradually transforms himself from a passive adjusted but dissatisfied worker into a conscientious radical rebel who eventually actively supports a syndicalist factory strike ${ }^{10}$.

In sum, Memoriale may be considered as a critical assessment of the Fordist system introduced on a large scale at the time in the economic triangle of the North of Italy [Cascione 2017a].

Ottiero Ottieri (1924-2002), a writer also strongly interested in psychology and sociology, started working for Olivetti in 1955 at the new model plant of Pozzuoli near Naples ${ }^{11}$. After a time Ottieri moved to the Olivetti headquarters at Ivrea (Milan), where he remained until 1965. Ottieri wrote three industrial novels based on his Olivetti experience: Tempi stretti [Ottieri 1957/1974], Donnarumma all'assalto [Ottieri 1959/2014] and La linea gotica [Ottieri 1963/2009], partly summarized in the fourth special number of Menabò [1961].

Most famous is his second novel, Donnarumma all'assalto [Ottieri 1959/2014]. The main theme in this novel is also worker alienation. The narrative protagonist

10 See for a concise content analysis of "Memoriale": Andrea Jackova [Jackova 2009], and on Volponi's work: Lothar Knapp [Knapp 2010], and Daniele Fioretti [Fioretti 2017]. In his book Fioretti compares the work of four authoritative postwar utopian Italian authors: Pasolini, Calvino, Sanguineti, and Volponi.

11 It was Adriano Olivetti's intention to contribute in a fundamental positive way to solving the socio-economic problems in the South caused by the at the time mass-migration from the South to the North by means of constructing a new sort of humanistic workmen's utopia in the Mezzogiorno (at Pozzuoli). 
of the book is a young company psychologist (apparently Ottieri himself) charged with the psycho-technical testing of many potential new factory workers on behalf of the Pozzuoli plant [in the novel Santa Maria], which produces calculators [see also Coratelli 2012]. This almost turned out to be a mission impossible because of the many conflicts and tensions between the company management and the workers, which arose over time in the new model factory (designed by famous Italian architect Luigi Cozenza). Unemployed and semi-literate Antonio Donnarumma was one of the workers after which the novel got its title, but in fact he represents the totality of the new southern workforce. He embodied the at the time typical traditional disordered mentality of the Mezzogiorno which at Pozzuoli was confronted with a rational bureaucratic company culture of a modern and progressive industrial company from the North. The book written in the form of a personal diary of the psychologist is strongly autobiographic.

The main message of this book and Ottieri's other industrial novels is that in the context of rapid urbanization and social uprooting of entire families, new modes of working and new products increasingly penetrated the sphere of private life of workers, touching also their intimate emotions [Cascione 2017b].

\section{MODERNIST INDUSTRIAL NOVELS AND INDUSTRIAL SOCIOLOGY}

Should industrial sociology make a more extensive use of relevant secondary sources in order to become a more enriched and more attractive sociological discipline? In this article I have tried to illustrate this on the basis of a selective case study of modernist industrial novels written in Weimar Germany and in 1950-1960s Italy. The in my view little used relevant secondary sources in industrial sociology are not only industrial novels written in successive time periods, but also for example novels or testimonies written by workingmen themselves, cinema, journalistic articles, policy documents or "blue books", and finally also artefacts like industrial architecture, remains of industrial culture and photographs. The choice for and focus on (modernist) industrial novels in this article was given by the fact that these to a large extent are based on, although partly partisan, pseudo-social or sociological research (questionnaires, (participant) observation, documents study, statistics) and for that reason are close to regular sociological methods ${ }^{12}$.

12 A comparable debate is taking place momentarily among historians with respect to making a more systematic use of historical artefacts, like novels, by the interpretation of important historical events [Schlögel 2017]. 
In case of Weimar Germany, in particular Kracauer's Die Angestellten (described as a mosaic of "in-depth dialectical unmasking" based on observation, interviewing and document study and resulting in a sharp diagnosis of the "spiritually empty" new white-collar mass culture in the Berlin and Germany of that time) seems a forceful example of a significant industrial novel close to formal industrial sociology. Moreover, in his book Kracauer meaningfully links the rise of white-collar workers and their specific new culture with the factual political and economic context of the Weimar republic.

The "spiritual emptiness" of the Weimar white-collar workers in principle has also much in common with the worker alienation process of the blue-collar workers at Olivetti, extensively described in the industrial novels of Volponi and Ottieri. In the Italian case however, worker alienation was not primarily caused by a new workers mass-culture as such, but by the clash of traditional family values and the introduction of the assembly line and Fordism in Italian industry in the $1950 \mathrm{~s}$ and $1960 \mathrm{~s}^{13}$.

\section{CONCLUSION AND DISCUSSION}

In this article I dealt with the industrial novel and its possible complementary significance for industrial sociology or sociology of work by paying attention to two remarkable groups of modernist industrial novels: the Weimar experience of the 1920s and early 1930s as well as the Italian post-war experience of the 1950s and early 1960s. These novels have in common that they emerged in the context of periods of intensive socio-economic and political change, strong and far reaching organizational changes (large scale introduction of scientific management and Fordism at the company level), strong migration and rapid urbanization, rising influence of rightist and leftist political parties, in particular national socialism in Weimar Germany and communism in both Weimar and post-war Italy.

Likewise, a substantial part of the modernist industrial novels of Weimar Germany and post-war Italy were not only based on narrative, but also on empirical facts and data. The respective authors collected these by means of interviews, participant observation, desk research and not in the least also by long-time personal experiences of the writers as collaborators of the companies about which they wrote (Krupp, Olivetti). The often chosen methodological form was the documentary (reportage, diaries). This turns their efforts also into ex-ante

13 This occurred in a context of rapid urbanization and industrialization as well as the advent of neo-capitalism and the consumer society. 
"pseudo" sociology or ethnography, which until today has not been taken into account sufficiently by industrial sociology. Also relevant is that the majority of the novels dealt with, enlarged their focus from the factory floor to the wider context of family life of workers, mass-migration, consumption and the new emerging workingman's culture.

Until today industrial sociology has been a practical, chiefly applied discipline at the company level almost neglecting the historical angle and relevant economic, cultural and political contexts. As a consequence, the main body of knowledge of industrial sociology has remained rather limited. From the viewpoint of the wider discipline this is regrettable. Therefore, in my view, by complementing more explicitly relevant secondary material as for example industrial novels, industrial sociology could be enriched substantially and at the same time develop into a more interesting sociological discipline as well ${ }^{14}$.

\section{REFERENCES}

Alberini Luca. 2014. "Civiltà delle macchine" 60 years later. Lett Mat Int 1: 157-159 (Springer). Bauman Zygmunt. 2000. Liquid modernity. Oxford: Polity Press.

Benjamin Walter. 1980. Gesammelte Schrifte. [Werkausgabe, Band 3]. Frankfurt am Main: Suhrkamp.

Bigatti Giorgio, Giuseppe Lupo. 2013. Fabbrica di carta. I libri che raccontano l'Italia industriale. Roma: Laterza.

Bonura Giuseppe. 1972. Invito alla lettura di Italo Calvino. Milano: Mursia Editore.

Bowlt John E. (ed.). 1988. Russian art of the avant-garde. Theory and criticism 1902-1934. London: Thames and Hudson.

Cascione Alberto. 2017a. Un "boom" nevrotico. L'Italia del dopoguerra sullo sfondo del romanzo Memoriale di Paolo Volponi. Pdf retrieved from the Internet [access August 2017].

Cascione Alberto. 2017b. Temi e problemi della letteratura industriale nei romanzi di Ottiero Ottieri. Pdf retrieved from the Internet [access August 2017].

Colombo Duccio. 2008. Scrittori, in fabbrica! Una lettura del romanzo industriale sovietico. Ospedaletto: Pacini Editori.

Corratelli Giorgio. 2012. La disciplina di fabbrica. Un studio tematico. Analisi di Donnarumma all'assalto di Ottiero Ottieri e Vogliamo tutto di Nanni Ballestrini. Impossibilita 4: 138-155.

Di Nardo Emmanuele. 2009. Impresa e cultura. "Civiltà delle Macchine" e la letteratura industriale. Università degli Studi di Bologna, Faccoltà di Letere e Filosofia. Pdf retrieved from the Internet, Tesionline: $2-8$ [acces August 2017].

Dos Passos John. 1938/1966. U.S.A. London: Penguin Books.

Eggers Dave. 2014. The Circle. New York: Vintage Books.

14 By what I have in mind also has a lot in common with the methods and theory applied by the former Frankfurt School of sociology, and more in particular with Walter Benjamin's approach. He considered social science chiefly as a cultural science [Benjamin 1980]. 
Ehrenburg Ilja. 1983. Das Leben der Autos. Stuttgart: Klein-Cotta.

Engels Friedrich. 1993. The condition of the working class in England. Oxford: Oxford University Press.

Ferrarotti Franco. 2015. Un imprenditore di idee. Roma/Ivrea: Communità Editrice (Kindle e-book).

Fioretti Daniele. 2013. Carte di fabbrica. La narrativa industriale in Italia (1934-1989). Pescara: Edizioni Tracce.

Fioretti Daniele. 2017. Utopia and dystopia in postwar Italian literature. Pasolini, Calvino, Sanguineti, Volponi. Cham: Palgrave Macmillan.

Gier Erik de. 2016. Capitalist workingman's paradises revisited. Corporate welfare work in Great Britain, the USA, Germany and France in the golden age of capitalism, 1880-1930. Amsterdam/Chicago: Amsterdam University Press (AUP). Also: Warsaw Forum of Economic Sociology 6: 1 (11) Spring 2015: 117-129.

Ginsborg Paul. 1989. Storia d'Italia dal dopoguerra a oggi. Torino: Einaudi.

Hermand Jost. 1965. Erik Regers "Union der festen Hand" (131): Roman oder Reportage? Monatshefte 57(3): 113-133.

Jackova Andrea. 2009. Paolo Volponi: "Memoriale" e la poetica dell'ordine industriale [Bachelor thesis]. Brno: Masaryk University, Faculty of Arts.

Jefffries Stuart. 2016. Grand Hotel Abyss. The Lives of the Frankfurt School. London: Verso.

Kaes Anton, Martin Jay, Edward Dimenberg. 1994. The Weimar Republic sourcebook. Berkeley: University of California Press.

Kisch Egon Erwin. 1924/2006. Der rasende Reporter. Berlin: Aufbau Taschenbuch Verlag.

Knapp Lothar. 2010. Paolo Volponi. Literatur als Spiegel der Geschichte: Italien von der nationalen Einigung bis zum Ende der Ersten Republik. Bielefeld: Transcript Verlag.

König René. 1987. Soziologie in Deutschland. Begründer, Verfechter, Verächter. Carl Hanser Verlag: München.

Kracauer Siegfried. 2013. Die Angestellten. Aus dem neuesten Deutschland. Frankfurt am Main: Suhrkamp.

More Thomas. 1965. Utopia. Harmondsworh: Penguin Classics.

Muller Françoise. 2014. Neue Sachlichkeit und Arbeitswelt. Germanica 9 (online).

Ochetto Valerio. 2013. Adriano Olivetti. La biografia. Roma/Ivrea: Communità Editrice (Kindle e-book).

Orwell George. 1937/1979. The road to Wigan Pier. Penguin Books: Harmondsworth.

Ottieri Ottiero. 1957/1974. Tempi stretti.: Torino: Einaudi.

Ottieri Ottiero. 1959/2014. Donnarumma all'assalto. Milano: Garzanti (Kindle-book).

Ottieri Ottiero. 1963/2009. La linea gotica. Milano: Mondadori.

Reger Erik. 1931/1992. Union der Festen Hand. Reinbek bei Hamburg: Rowohlt Taschenbuch Verlag.

Schlögel Karl. 2017. "Das Leben der Dinge. Materielle Kultur als Wahrnemungsregister der Russischen Revolution". Lettre International 118: 66-73.

Später Jörg. 2016. Siegfried Kracauer. Eine Biographie. Frankfurt am Main: Suhrkamp.

Todorov Tzvetan. 2009. La signature humaine. Essais 1983-2008. Paris: Editions du Seuil.

Vittorini Elio. 1961. Industria e Letteratura. Menabò 4. Einaudi: Torino.

Volponi Paolo. 1962/1974. Memoriale. Torino: Einaudi.

Volponi Paolo. 1974. Corporale. Torino: Einaudi.

Volponi Paolo. 1989. Le Mosche del capitale. Torino: Einaudi. 
Williams Keith. 1990. The will to objectivity: Egon Erwin Kisch' "Der rasende Reporter". The Modern Language Review 85(1): 92-106.

Williams Raymond. 1963. Culture and society 1780-1950. Harmondsworth: Penguin Books. Zingarelli lo. 2017. Dizionario. Bologna: Zanichelli editore.

Zola Émile. 1885/1991. Germinal. Paris: Fasquelle (Le Livre de Poche).

\author{
Erik de Gier
}

\title{
NOWOCZESNE POWIEŚCI PRZEMYSLOWE A SOCJOLOGIA PRZEMYSLU. PORÓWNANIE MIĘDZY WEIMARSKIMI NIEMCAMI I WLOCHAMI PO II WOJNIE ŚWIATOWEJ.
}

\begin{abstract}
Streszczenie
Od czasów rewolucji przemysłowej w Anglii w XVIII wieku powieść przemysłowa odgrywała znaczącą role w krajach uprzemysłowionych w uświadamianiu pracowników, polityków i opinii publicznej o rzeczywistych warunkach pracy w przemyśle i usługach. Dobrze znanymi przykładami są powieści przemysłowe pisarzy angielskich epoki wiktoriańskiej, Dickensa i Gaskell. W innych krajach powieść przemysłowa rozwinęła się również w dobrze znany gatunek związany z procesami uprzemysłowienia. We Francji, "naturalistyczne” powieści przemysłowe Zoli wywarły znaczący wpływ na politykę dotyczącą świata pracy w okresie Trzeciej Republiki. Na przełomie XIX i XX wieku, powieści przemysłowe zaczęły powstawać również w innych krajach uprzemysłowionych: przed I Wojną Światową w USA, w okresie międzywojennym w Niemczej i ZSRR, a po II Wojnie Światowej we Włoszech. Powieści te opierały się często na badaniach w oparciu o dane zastane oraz badania empiryczne w terenie. $W$ tym sensie, powieści te są również przejawami pseudosocjologii lub socjologii ex ante, niedocenianymi niestety przez istniejącą socjologię przemysłu. W artykule ilustruję tą tezę, porównując i zestawiając ze sobą powieści przemysłowe napisane w dwóch ważnych krajach europejskich, w dwóch odmiennych okresach czasu, Niemczech okresu Republiki Weimarskiej w latach 20. XX wieku oraz powojennych Włoszech w latach 50 i wczesnych latach 60. XX wieku
\end{abstract}

Słowa kluczowe: powieści przemysłowe, socjologia przemysłu, socjologia pracy, historia pracy 